\title{
II rilievo digitale di una fabbrica del Quattrocento: la Sagrestia Vecchia di San Lorenzo
}

\author{
Matteo Bigongiari
}

Abstract

Il paper descrive il progetto di documentazione e rilievo architettonico digitale della Sagrestia Vecchia del complesso di San Lorenzo a Firenze, progettata da Filippo Brunelleschi. Dopo aver brevemente descritto le condizioni storiche e culturali che portarono alla progettazione urbana di un nuovo complesso per San Lorenzo, all'interno del quale la Sagrestia fu il primo edificio costruito, seguendo il nuovo gusto di stili e proporzioni che si rifacevano all'architettura antica, vengono descritte le metodologie di rilievo digitale che sono state necessarie per impostare un progetto di documentazione che vada ad indagare ed approfondire le vicende storiche e costruttive della fabbrica. Le particolari condizioni di pandemia hanno impedito di completare le acquisizioni fotografiche delle superfici fino a dopo l'estate di questo anno, motivo per cui i disegni e i rilievi architettonici di dettaglio delle superfici sono stati eseguiti seguendo le indicazioni morfo-metriche fornite dal solo dato proveniente da laser scanner: questa particolare condizione ha fornito l'occasione di indagare le criticità descrittive delle nuvole di punti, specialmente quando si affrontano architetture con elementi architettonici complessi come l'oggetto di questo articolo. Infine vengono illustrate le intenzioni e la direzione della futura ricerca che partendo dai rilievi acquisiti approfondirà le tematiche della costruzione e stratificazione del complesso con l'intento di divulgare le informazioni attraverso sistemi di fruizione interattiva digitale.

Parole chiave

Sagrestia Vecchia, Brunelleschi, Rinascimento, disegno, rilievo digitale.

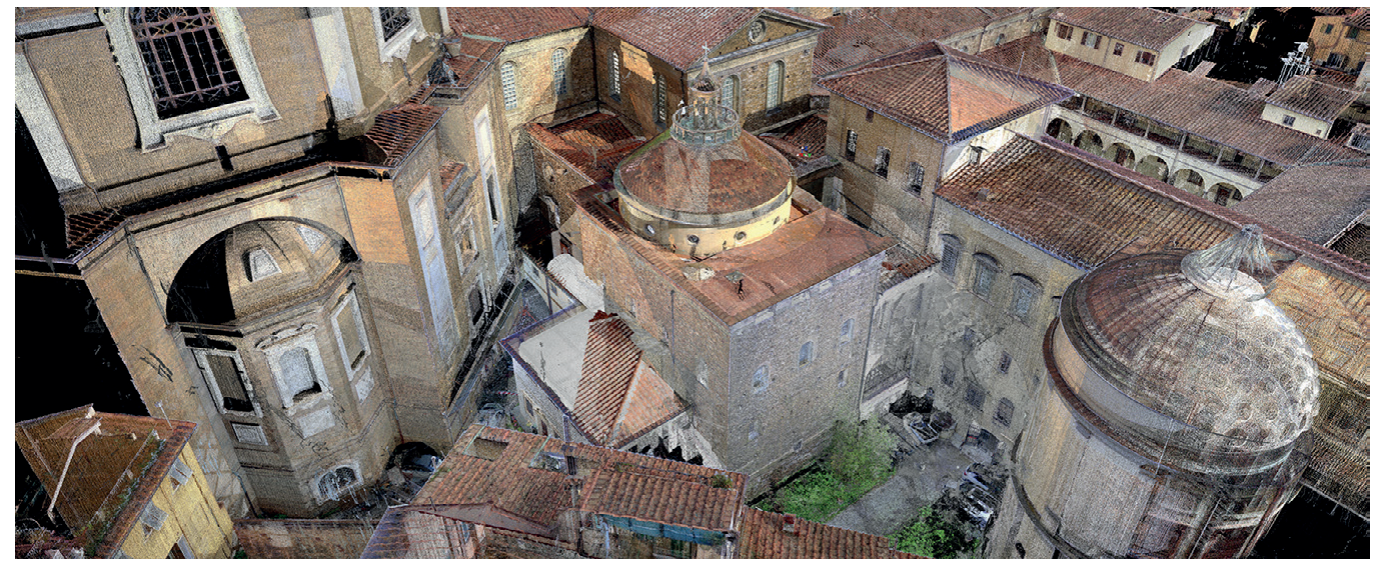




\section{Introduzione}

Nel febbraio 2020 è iniziato un progetto di ricerca sul complesso di San Lorenzo, volto a restituire, come primo caso campione, l'immagine e le forme di uno degli edifici che più rappresentativi della nuova architettura del Rinascimento fiorentino: la Sagrestia Vecchia del Brunelleschi.

Questo articolo, introducendo l'edificio nel contesto storico e culturale in cui è stato realizzato, illustra le metodologie di rilievo architettonico digitale adottate e i primi risultati ottenuti dalle restituzioni grafiche, proponendo alcune preliminari considerazioni da sviluppare all'interno del progetto per accrescere le conoscenze dell'edificio, con particolare attenzione alla disseminazione a valorizzazione dei prodotti della ricerca.

Produrre una ricerca riguardo edifici molto noti e studiati nasconde sempre il rischio di non ottenere risultati innovativi dal punto di vista storico e architettonico, nonostante l'indiscutibile qualità grafica che si prevede di ottenere dai disegni, dovuta principalmente all'importanza dell'oggetto. L'avvicinamento allo studio delle architetture prodotte da artisti importanti del Rinascimento ha comunque già evidenziato in altre ricerche [I] come un approccio conoscitivo olistico, e fortemente incentrato sull'analisi morfologica delle architetture sulla base di un rilievo altamente affidabile, possa mettere in risalto caratteristiche e informazioni tralasciate dalle ricerche precedenti. Allo stesso modo le forti convinzioni scientifiche, relative ad architetture ormai divenute simbolo di un movimento culturale di rinascita e riscoperta delle tradizioni compositive e funzionali romane, meritano di essere studiate ed analizzate in relazione al proprio contesto culturale di profonda mutazione delle caratteristiche formali e decorative degli spazi pubblici e sacrali. Ė allo stesso modo vero che rispetto ad altri grandi architetti del rinascimento maturo, personaggi come Brunelleschi non hanno passato negli ultimi decenni un periodo fortunato dal punto di vista dell'interesse degli studiosi, soprattutto a causa della scarsa documentazione relativa al lavoro dell'architetto fiorentino, nonostante sia uno dei pochi ad aver avuto un biografo personale che si è anche occupato di completare i molti lavori lasciati incompiuti alla morte di Filippo, come appunto il complesso di San Lorenzo.

\section{Brevi cenni su un progetto del ‘ 400}

Analizzare le forme dell'architettura, richiede una forte attenzione a tutte le componenti che ne hanno provocato la realizzazione, in particolare alle condizioni a contorno del contesto, sia storico-culturale che strettamente morfologico-urbanistico. La realizzazione di una delle architetture simbolo della modernità rinascimentale si deve in principio alla abolizione degli ordini monastici che provocarono la necessità di rafforzare politicamente San Lorenzo rendendolo un polo religioso culturale, ben funzionante e virtuoso per la città di Firenze; tutto questo avveniva prima che i Medici decidessero, dopo la metà del 400 di assumersi privatamente l'accrescimento del complesso, come chiesa di famiglia [Battisti 1976].

L'ingrandimento della preesistente basilica medievale prevedeva l'ingrandimento della parte tergale del complesso, con la costruzione di un grande transetto con sagrestie e cappelle [Pacciani 1995]; per prima venne realizzata la sagrestia del Brunelleschi tra il I 422 e il I 428, successivamente il resto del transetto con numerose modifiche progettuali, dovute principalmente alla morte del priore, alla necessità di finanziare la costruzione della costosa fabbrica e del sempre più presente supporto della famiglia medici. È possibile vedere in una illustrazione del Codice Rustici come doveva apparire la chiesa durante l'edificazione del transetto, con la basilica ancora esistente e funzionante fino al 1465 e la completata Sagrestia Vecchia: è evidente come il progetto gradualmente, probabilmente proprio su suggerimento di Brunelleschi, portò alla nuova edificazione dell'intero edificio religioso, modificando completamente le prime intenzioni progettuali. In un primo momento infatti era previsto l'aggiunta di un corpo trasversale su due livelli che si doveva connettere con l'edificio antico, successivamente l'edificio antico venne esso stesso demolito e sostituito dall'attuale navata che nasconde al livello inferiore un intero piano, non percepito dall'esterno grazie all'inserimento della grande scalinata che circonda il monumento. Allo stesso modo anche la sagrestia di Brunelleschi 


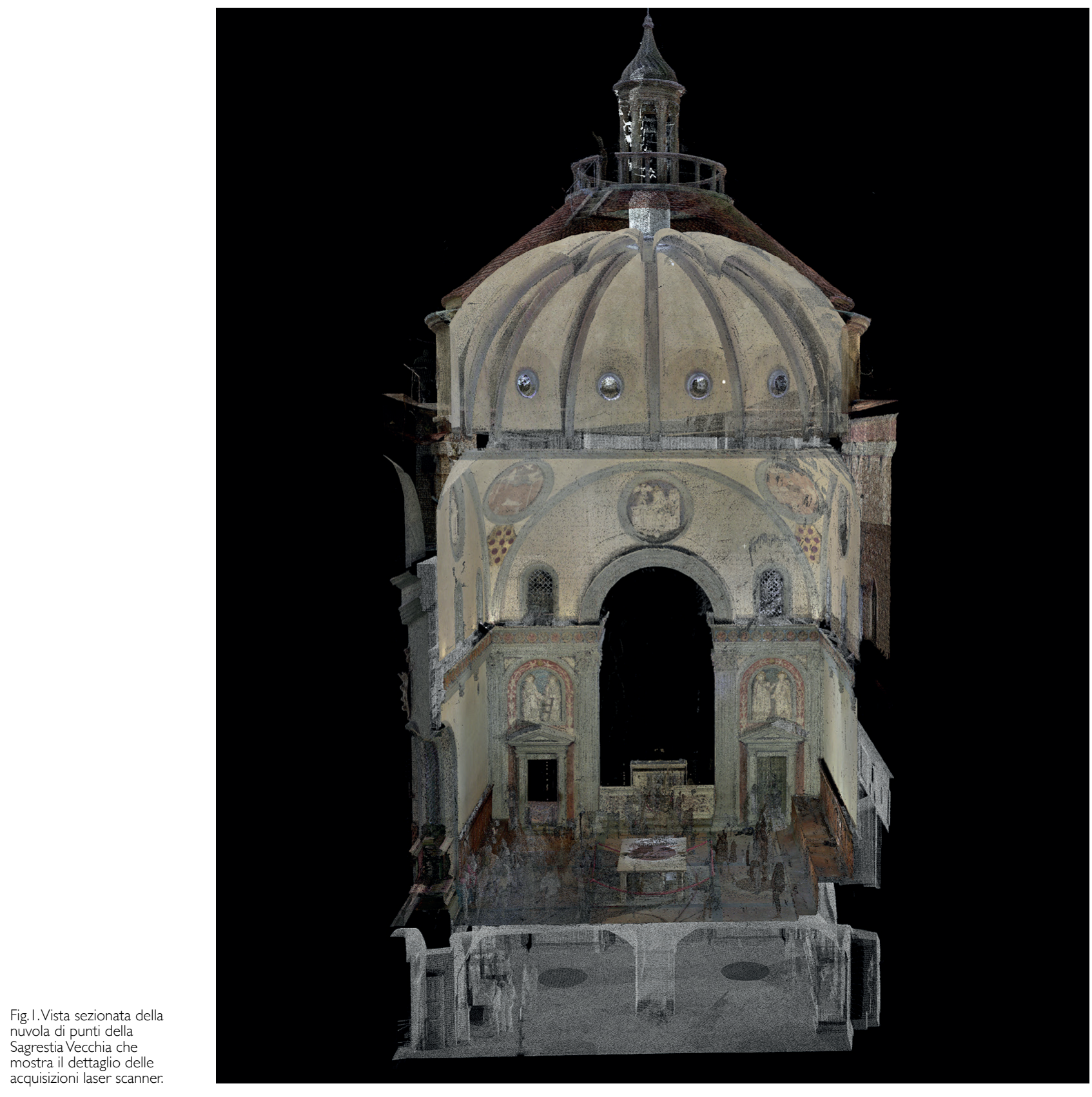

venne progettata su due livelli, un livello voltato all'altezza delle fondazioni del futuro transetto e la quota di calpestio attuale: il basamento su cui è realizzato il piano elevato della sagrestia si può osservare ancora dall'esterno del complesso. Questa suddivisione ha portato a ipotizzare che l'esterno dell'edificio fosse allo stesso modo dell'interno pensato in modo tale da ricreare l'idea di un ordine architettonico: doveva apparire intonacato, poggiato su un basamento, e coronato da una trabeazione. II volume dell'edificio oggi appare notevolmente differente rispetto alla costruzione originaria, in particolare nel lato della scarsella, dove le strutture di copertura sono state completamente nascoste da interventi successivi che hanno alterato la percezione dell'edificio dall'esterno, oltre all'aggiunta di numerosi fabbricati attorno ad esso. Non è necessario ribadire in questa occasione l'innovativa concezione dello spazio interno dell'edificio dove l'architetto è riuscito brillantemente a coniugare una pianta quadrangolare con l'inserimento di una cupola circolare [Bruschi 2006]. 
Fig. 2. Planimetria de piano terreno della Sagrestia Vecchia dove si può comprendere la relazione con gli spazi turgici del transetto del complesso di San orenzo.

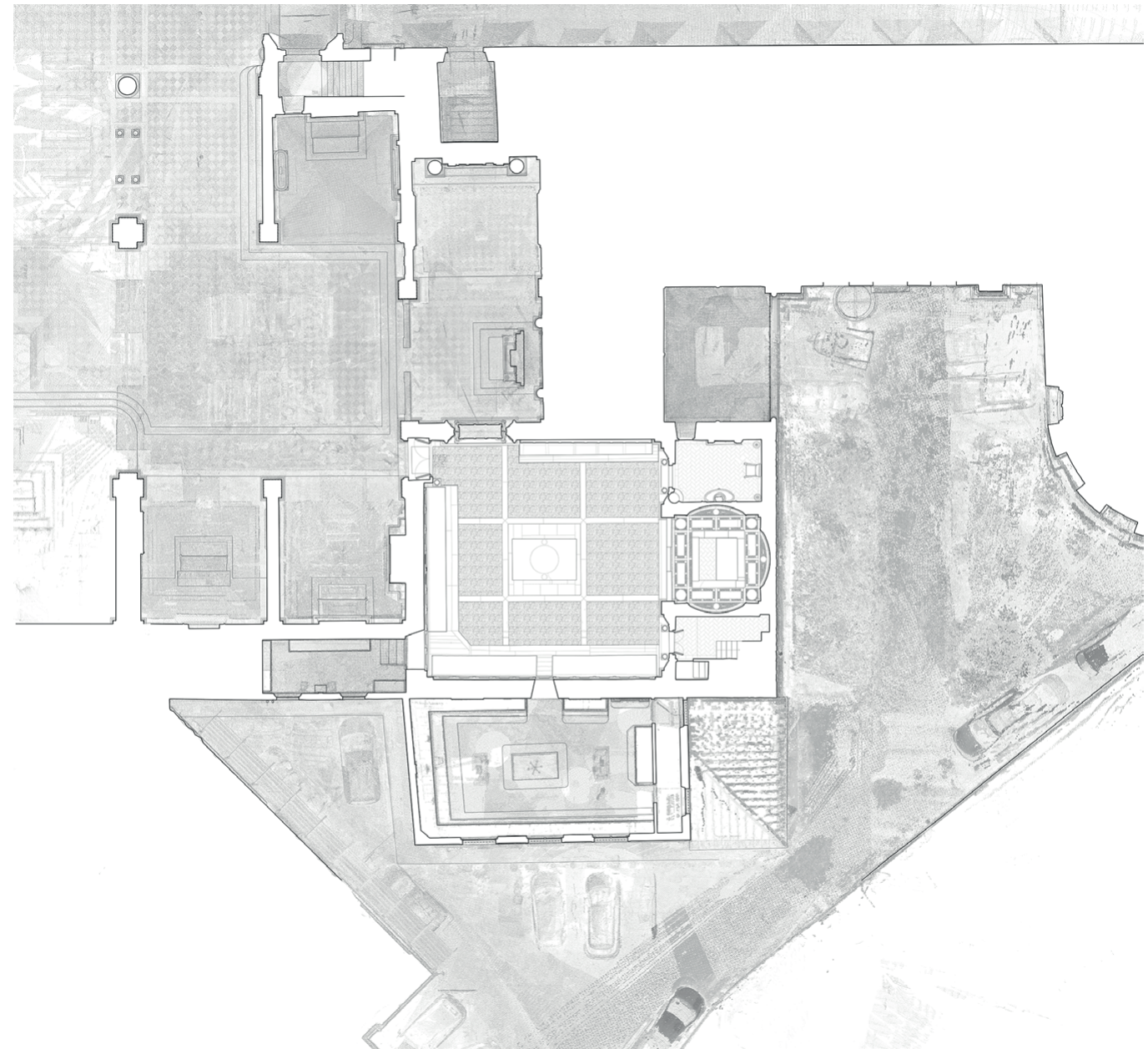

\section{II rilievo architettonico della sagrestia}

Lo studio dell'architettura di Brunelleschi nella Sagrestia Vecchia non poteva iniziare senza un primo momento di conoscenza diretta dell'edificio; per questo motivo nel febbraio del 2020, pochi giorni prima della chiusura del paese per l'emergenza sanitaria, è iniziata una campagna di rilievi digitali volti a ricostruire la morfologia della costruzione quattrocentesca. In un primo momento sono state progettate le acquisizioni di scansioni tridimensionali con laser scanner dei locali che compongono la sagrestia: purtroppo, a causa dellimprevista chiusura dei locali nel Marzo 2020, non è stato possibile integrare i dati fotografici fino al settembre dello stesso anno, imponendo di restituire il rilievo digitale in un primo momento solo con le scansioni come unico strumento a disposizione [2]; la documentazione fotografica non era del tutto assente: quella necessaria per descrivere i singoli elementi architettonici era stata correttamente acquisita, deve essere inoltre considerato che da ogni singola scansione è stato possibile estrarre una fotografia panoramica ad alta risoluzione; non è stato possibile però restituire il dettaglio dei singoli elementi architettonici a partire da un fotopiano in scala adeguata, ma semplicemente dalle nuvole di punti laser scanner. I modelli tridimensionali fotogrammetrici sono stati realizzati in un secondo momento andando ad integrare i risultati della restituzione a filo di ferro.

II rilievo laser scanner della sagrestia vecchia è stato progettato in modo tale da ottenere un dato adeguato a consentire la descrizione di tutti gli elementi che caratterizzano lo spazio interno dell'edificio, considerando che proprio la caratteristica principale del progetto brunelleschiano consiste nella realizzazione di uno spazio semplice dove le pareti intonacate, che costituiscono gran parte delle superfici del primo registro, dovevano 
Fig. 3. Sezione verticale della Sagrestia che mostra l'accesso alla scarsella e la relazione volumetrica con le strutture circostanti.

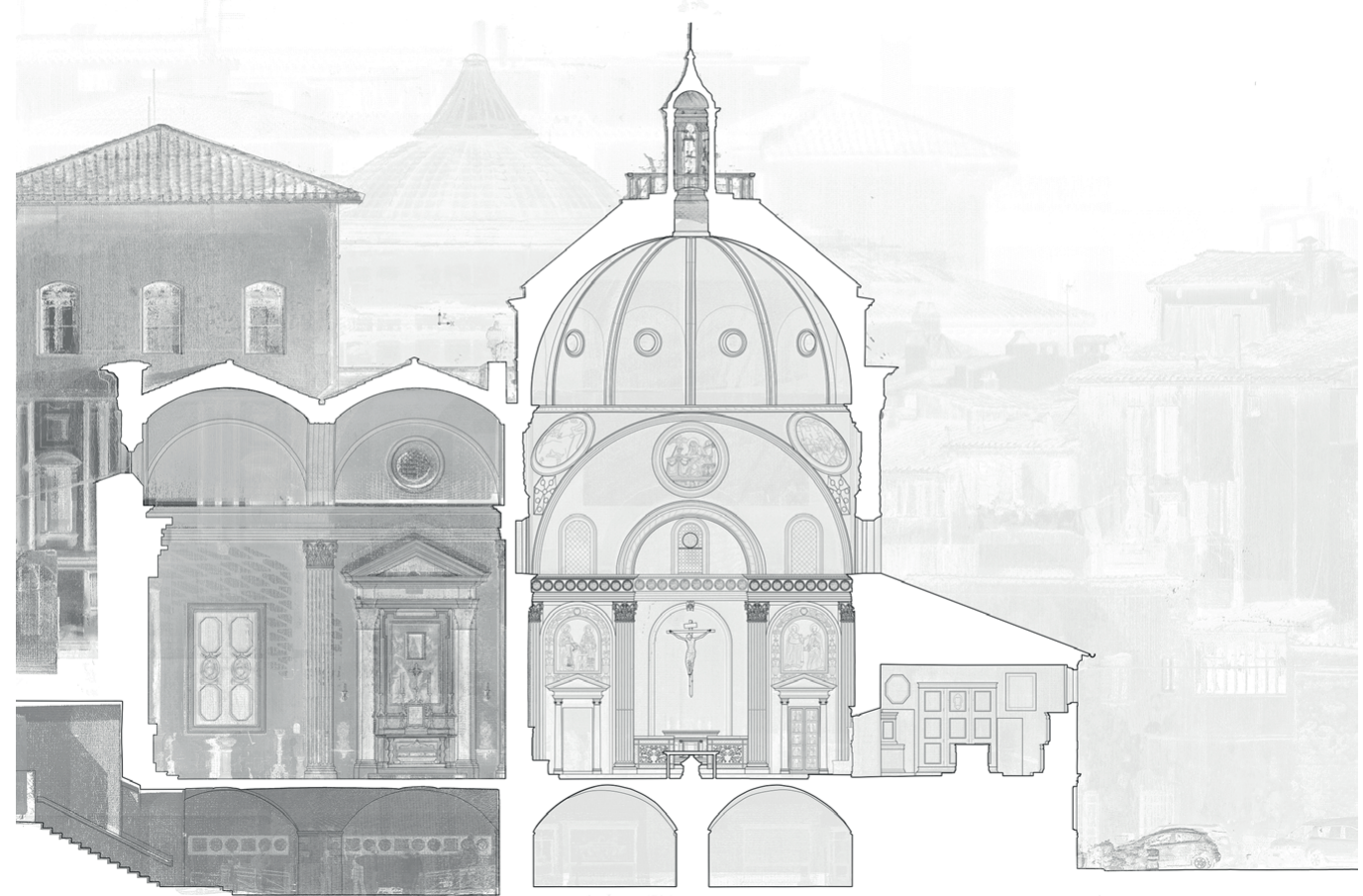

esaltare il contrasto con l'ordine classico, formato da paraste corinzie che scandiscono il ritmo dell'architettura. Le scansioni sono state dunque progettate in modo tale da garantire una elevata copertura di punti per quelle superfici complesse, come le paraste rudentate, i capitelli corinzi, i cherubini in terracotta del fregio, gli elementi decorativi delle trabeazioni, $i$ tondi e la parete che inquadra la scarsella, per citarne alcune; ovviamente come è facilmente intuibile, la necessità di definire nel dettaglio la nuvola di punti di questi elementi ha provocato un generale aumento di dimensioni del database morfologico della sagrestia, e ha inoltre richiesto la corretta progettazione di acquisizione del dato: è stato infatti utilizzato uno strumento che garantisce una elevata affidabilità nelle misurazioni, e le scansioni sono state realizzate in modo tale da limitare al massimo i problemi derivanti dal "rumore digitale" che si crea abitualmente ogni volta che il raggio laser incontra uno spigolo [3]. L'esterno della sagrestia e gli ambienti interni non riccamente decorati come la sala principale ed il sacello hanno richiesto un dato meno denso e sono stati acquisiti più rapidamente.

La gestione del dato delle scansioni ha previsto una adeguata fase di filtro per limitare ulteriormente errori nei puniti acquisiti; la fase di registrazione delle scansioni, grazie alla moderna tecnologia dello strumento utilizzato [4], ha inizio mentre procede l'acquisizione delle scansioni: una volta acquisito il dato questo viene trasferito direttamente tramite wi-fi ad un computer, e pre-allineato con le scansioni precedenti, cosa che consente di terminare il rilievo in campo con tutte le scansioni correttamente orientate in un unico sistema di riferimento. La fase di registrazione in post produzione ha dunque richiesto l'ottimizzazione del pre-allineamento [5] e una successiva fase di certificazione del dato attraverso l'analisi dei profili di sezione delle scansioni che ha permesso di stabilire il grado di affidabilità della registrazione [6]. Dal modello generale ottenuto sono state estratte le ortoimmagini ad alta definizione utili alla lucidatura delle principali sezioni su AutoCad, riconducendo la nuvola di punti ad un disegno CAD che riuscisse a suddividere sia gli oggetti dal punto di vista semantico sia dal punto di vista del peso grafico delle linee nella rappresentazione. 
Fig. 4. Dettaglio da nuvola di punti di una parasta corinzia della Sagrestia nonostante l'elevato dettaglio a relevato dettaglio, a d'ousa di aggetti e zone dombra non e possibile comprendere facilmente tutti i contorni che

descrivono l'architettura.

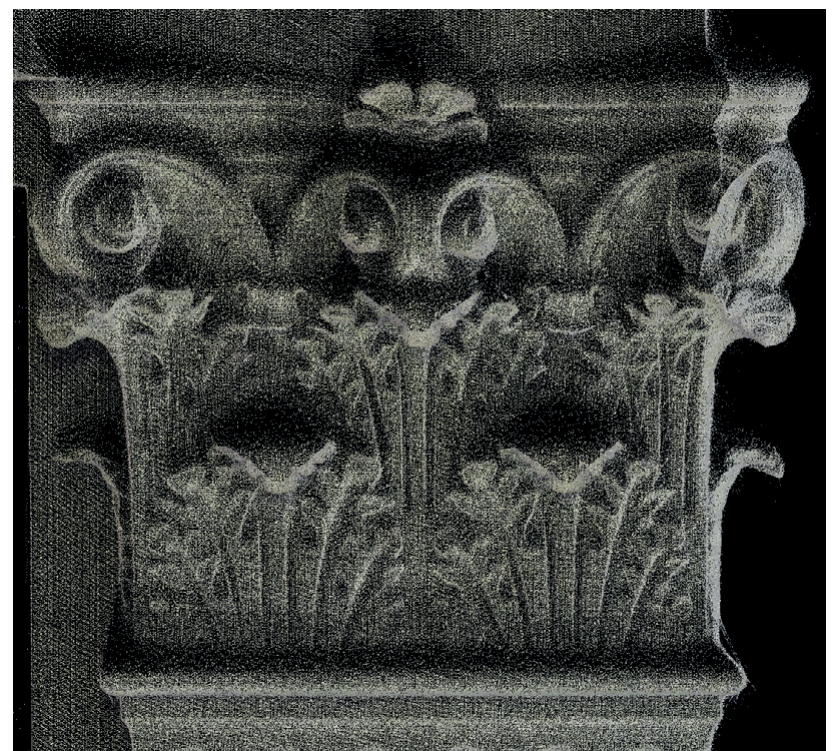

\section{Le problematiche del rilievo digitale}

La particolare condizione in cui sono stati restituiti graficamente gli elaborati di rilievo della sagrestia vecchia ha permesso di approfondire alcune riflessioni sulle problematiche legate all'interpretazione delle nuvole di punti: come è stato anticipato l'emergenza sanitaria ha costretto studenti e docenti a svolgere l'attività di rilievo principalmente da casa, sfruttando il solo dato proveniente dalle scansioni laser scanner prodotte in una rapida giornata di misurazioni. La sfida principale è stata quindi verificare se le informazioni morfologiche ottenute dalle scansioni $3 \mathrm{~d}$ fossero sufficienti per riuscire a comprendere e le forme dell'architettura e a disegnarne elaborati tecnici, ovvero rilievi architettonici anche a scala di dettaglio. A rendere ulteriormente complicata la restituzione grafica sono state le caratteristiche compositive dell'edificio, ovvero la presenza di elementi architettonici particolarmente ricchi nelle decorazioni, con la presenza di particolari scolpiti e di numerosi bassorilievi. La problematica presenza di elementi riccamente decorati mette in evidenza una problematica intrinseca degli strumenti laser scanner comunemente utilizzati per i rilievi architettonici, che consiste nel non riuscire a definire correttamente gli spigoli delle superfici, che sono invece per quanto riguarda il disegno i punti necessari per definire i contorni degli oggetti [Rinaudo 2017]. Questa difficoltà viene risolta nel rilievo architettonico con una acquisizione di punti talmente massiva da ridurre al minimo l'errore nella rappresentazione rispetto alla scala di restituzione del disegno, a discapito però di una archiviazione eccessiva di informazioni morfologiche, tale da non consentire la rapida gestione delle banche dati, e per lo più spesso non necessarie: per quanto riguarda la Sagrestia, ad esempio, se un dato molto denso di punti è utile per la corretta interpretazione dell'ordine architettonico, allo stesso tempo la maggior parte delle superfici sono intonacate e non necessitano della stessa densità di acquisizione. Una ulteriore complessità nella corretta definizione e comprensione del rilievo deriva dalle evidenti mancanze di dato dovute all'aggetto di alcuni elementi decorativi: questo problema non è risolvibile in fase di acquisizione direttamente con un laser scanner terrestre, owvero non si può ovviare alla mancanza di dato digitale; per risolvere la questione si deve invece porre attenzione in fase di rilievo sul campo e registrare le forme dell'architettura. Per tali questioni rimane insostituibile la figura dell'architetto che non solo riesce a comprendere e integrare il dato digitale assente, ma conoscendo le forme dell'architettura classica è in grado di distinguere anche in presenza di rumore digitale le caratteristiche morfologiche degli elementi decorativi e architettonici dell'ordine classico e tradurli in disegni comprensibili e morfologicamente corretti [Migliari 199I]. 
Fig. 5. Modello fotogrammetrico della Sagrestia utile per l'integrazione del dato colore.

Fig. 6. Confronto tra modelli fotogrammetric il primo da sinistra è stato realizzato creando una mesh a partire dal solo dato laser scanner; il secondo dal dato fotografico (ottenuto da una Sony alfa7); il terzo integrando entrambi i dati scanner e fotografici. É evidente cometografici. E evidente come il primo modello garantisca una morfologia plu adeguata a descrivere le forme

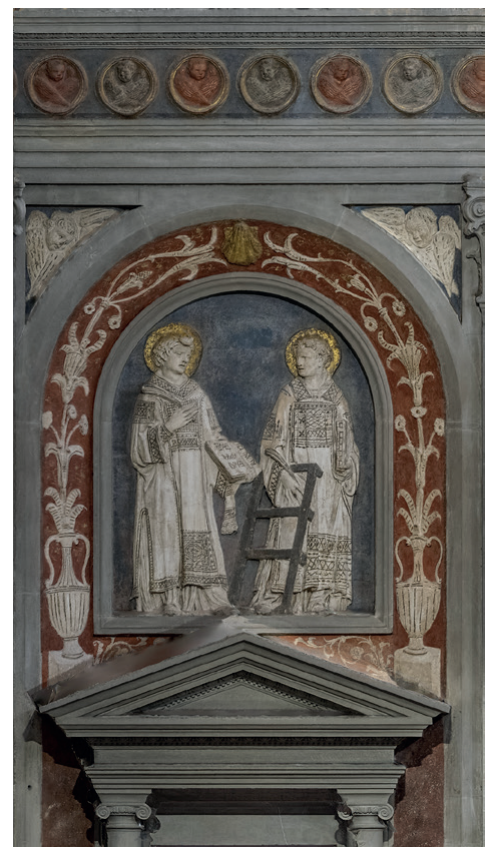

\section{Conclusioni e sviluppi del progetto}

Come si può vedere dalle immagini che illustrano i risultati delle elaborazioni grafiche, è stato possibile raggiungere un elevato grado di definizione attraverso il solo disegno sulla base della nuvola di punti laser scanner. La costruzione delle texture è iniziata solo dopo la realizzazione dei disegni e porterà ad integrare tutte le superfici con il dato del colore; la presenza di numerose pareti intonacate ha richiesto di valutare nella ricostruzione fotogrammetrica di integrare informazioni provenienti da camere fotografiche e laser scanner, portando ad interessanti risultati.

I rilievi architettonici realizzati attraverso questo progetto di documentazione permettono di descrivere con un adeguato approfondimento tutti i paramenti murari della Sagrestia del Brunelleschi: questi dati saranno necessari, insieme ai prodotti di una adeguata ricerca sto-
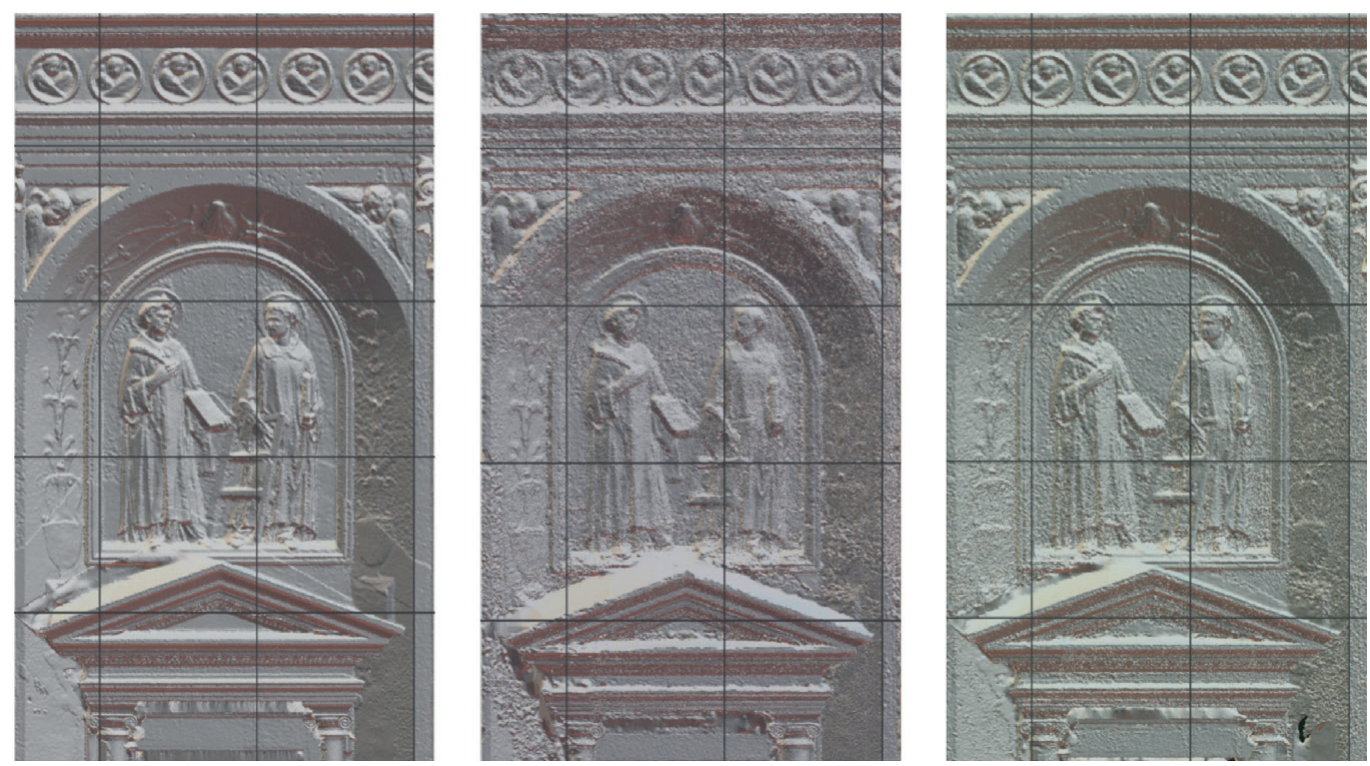
Fig. 7. Texture proveniente dalla colorazione dei modelli descritti nell'immagine precedente, il dettaglio sulle decorazioni di Donatello ha permesso di verificare la correttezza del disegno a filo di ferro.

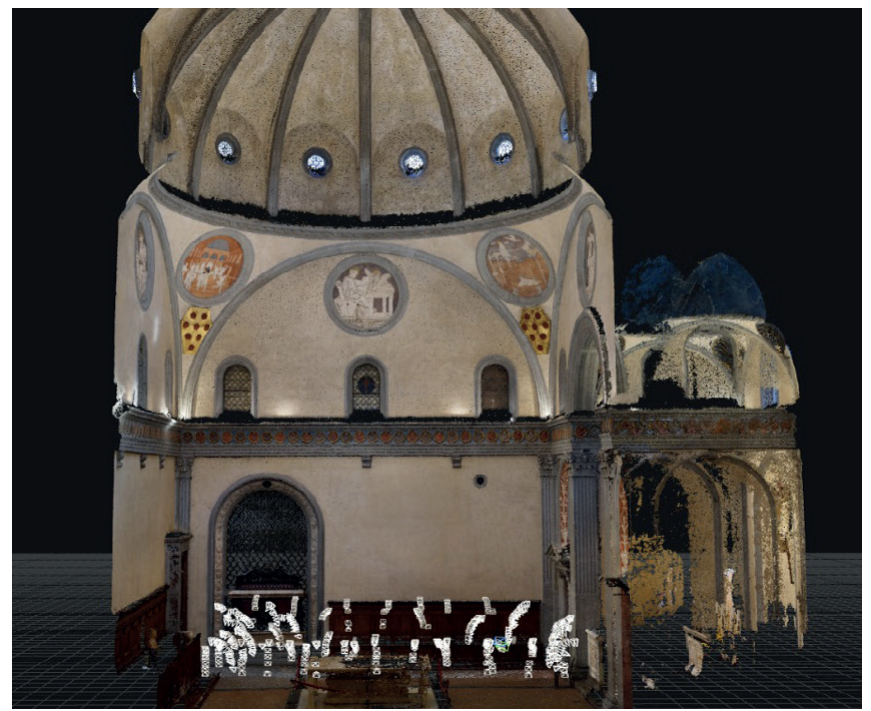

rico archivistica, per approfondire i processi di progettazione, costruzione e stratificazione che si sono susseguiti nella fabbrica di San Lorenzo.

I rilievi hanno fornito l'occasione di paragonare i disegni eseguiti dal Sanpaolesi alla meta del '900 e quelli più approfonditi pubblicati da Gurrieri, per verificare il dato morfologico e le informazioni riguardanti le strutture della sagrestia, integrando comunque gran parte del decoro interno e restituendo una immagine più completa dell'architettura della sagrestia. L'attenta analisi della costruzione brunelleschiana mostrerà come il tema della progettazione di cappelle quadrate con cupola su pennacchi non fosse completamente risolta nell'esempio progettuale della Sagrestia Vecchia: non è questa l'occasione per approfondire l'argomento ma evidenti incongruenze sulla modulazione dell'ordine sono tutt'ora in parte visibili ed in parte nascoste dalla realizzazione del collegamento successivo con il transetto; per chiarire questo aspetto sarà necessario un attento paragone con la Cappella Pazzi, costruita successivamente alla Sagrestia Vecchia, per la quale è appena iniziato un nuovo progetto di documentazione digitale. I disegni ottenuti saranno fondamentali per la ricostruzione delle fasi di costruzione della fabbrica, per cui sarà necessaria una attenta analisi delle stratigrafie murarie almeno per quanto riguarda i fronti esterni in pietra forte; la presenza di un rilievo tridimensionale di dettaglio potrà essere il punto di partenza per la costruzione di modelli digitali che illustrino la realizzazione del fabbricato e la successiva evoluzione, valorizzando e mostrando al pubblico, attraverso l'utilizzo di piattaforme di realtà virtuale la storia del monumento, che doveva esser stato pensato per avere una un'immagine esterna ed una illuminazione completamente differente da quanto possiamo vedere oggi.

\section{Note}

[I] Per un contributo innovativo sulle architetture militari di Leonardo da Vinci vedi Bertocci, Bigongiari 202 I.

[2] II rilievo architettonico della sagrestia è stato oggetto di un seminario di rilievo digitale svolto allinterno del programma didattico della Scuola di Specializzazione in Beni Architettonici e del Paesaggio del Dipartimento di Architettura.

[3] Nello specifico è stato utilizzato uno strumento Z+F 5016, che presenta errori nominali sulle misurazioni inferiori ad I mm; ogni scansione è stata realizzata in modo tale da garantire una copertura di punti elevata su ogni superficie, almeno 4 punti ogni cm, ed a una qualità elevata, cosa che ha richiesto di misurare ogni punto almeno 4 volte, limitando in questo modo eventuali problemi di rumore digitale.

[4] Lo strumento possiede sensori interni, piattaforma inerziale e GPS, che consentono ai software di gestione del dato direttamente in campagna di riconoscere gli spostamenti delle stazioni laser scanner

[5] La gestione della registrazione finale è stata realizzata con il software Leica Cyclone 9.4.

[6] II problema della certificazione dell'errore di allineamento in un rilievo laser scanner realizzato senza alcun altro metodo di rilievo di appoggio (topografico o gps) è un argomento di ricerca che ha permesso di velocizzare notevolmente il rilievo architettonico [Bigongiari 2020]. 
Fig. 8. Fotopiano dell'esterno della cupola della Sagrestia, dove è possibile vedere singolare struttura con cupola di gusto arabeggiante posizionata sulla sommità (restauro di Sanpaolesi).

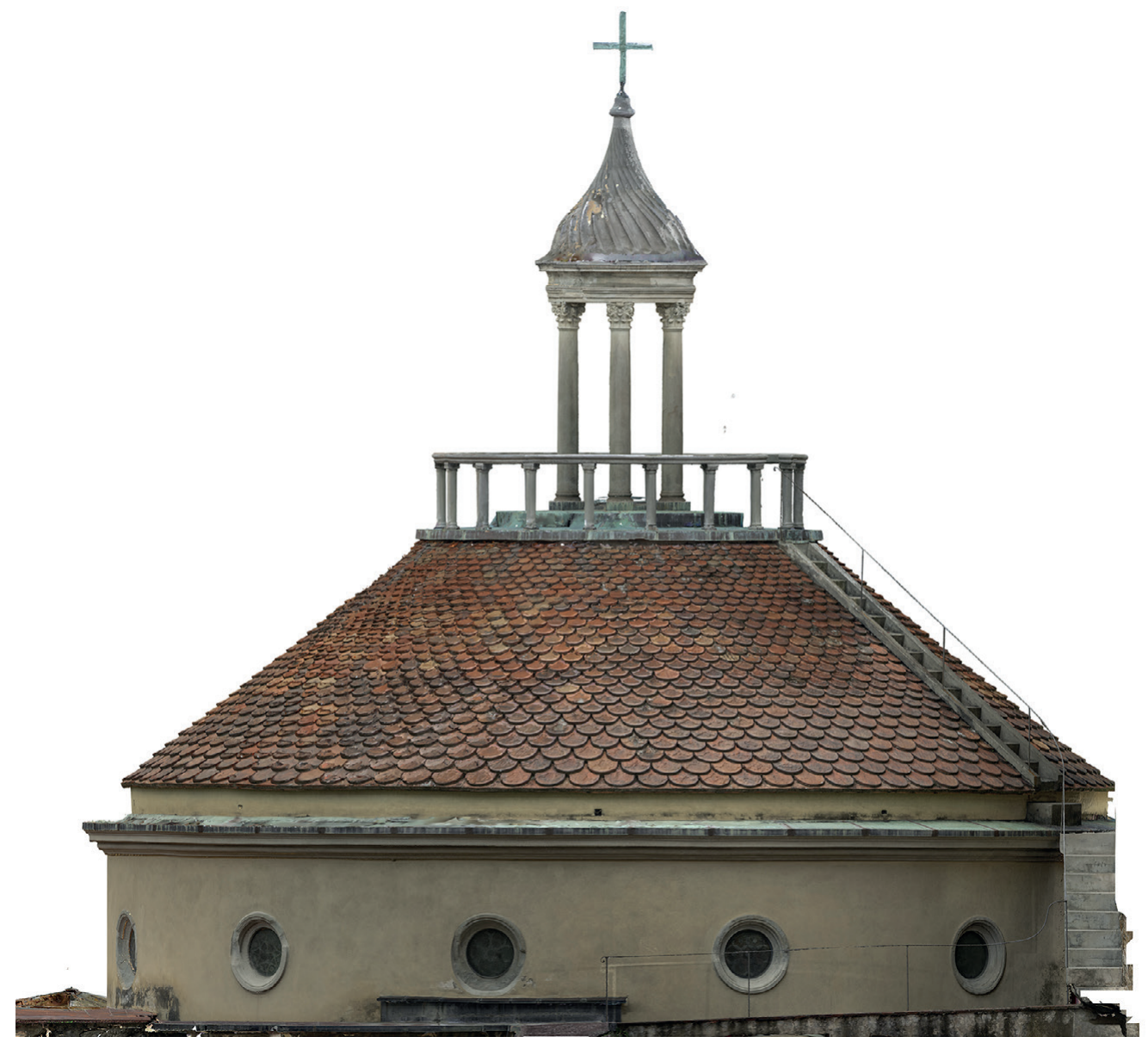

Riferimenti bibliografici

Battisti E. ( 1976). Filippo Brunelleschi. Milano: Electa.

Bertocci S., Bigongiari M. (2020). Le fortificazioni di Piombino di Leonardo da Vinci: la riscoperta delle tracce dell'impianto rinascimentale attraverso il rilievo digitale e il disegno. In Arena A. et al. (a cura di). Connettere. Un disegno per annodare e tessere. Atti del $42^{\circ}$ Convegno Internazionale dei Docenti delle Discipline della Rappresentazione/Connecting. Drawing for weaving relationships. Proceedings of the 42th International Conference of Representation Disciplines Teachers. Milano: FrancoAngeli, pp. 87 - I02.

Bigongiari M. (2020). La cattedrale di Sasamòn. Rilievo digitale e strutturale per la conservazione del Patrimonio. Firenze: Didapress. Bruschi A. (2006). Filippo Brunelleschi. Milano: Electa.

Migliari R. (|99|). II disegno degli ordini e il rilievo dell'architettura classica: 5 pezzi facili. In Disegnare. Idee Immagini, n. 2, pp. 49-66.

Pacciani R. (1995). Testimonianze per l'edificazione della basilica di San Lorenzo a Firenze, | 42 I - |442. In Prospettiva, n. 75-76, pp. 85-99.

Rinaudo F. (2017). Analisi della qualità del rilievo laser scanner architettonico e criteri di verifica, In G. Pancani. La città dei Guidi: Poppi Il costruito del centro storico, rilievi e indagini diagnostiche. Firenze: Firenze.

Sanpaolesi P. (1947). Brunellesco e Donatello nella Sacrestia Vecchia di San Lorenzo. Pisa: Nistri-Lischi Editori.

\section{Autore}

Matteo Bigongiari, Università di Firenze, matteo.bigongiari@unifi.it

Per citare questo capitolo: Bigongiari Matteo (202I). Il rilievo digitale di una fabbrica del Quattrocento: la Sagrestia Vecchia di San Lorenzo/Digital Survey of a Building Site of the Fifteenth Century: the Sagrestia Vecchia in San Lorenzo. In Arena A., Arena M., Mediati D., Raffa P. (a cura di). Connettere. Un disegno per annodare e tessere. Linguaggi Distanze Tecnologie. Atti del $42^{\circ}$ Convegno Internazionale dei Docenti delle Discipline della Rappresentazione/Connecting. Drawing for weaving relationship. Languages Distances Technologies. Proceedings of the 42th International Conference of Representation Disciplines Teachers. Milano: FrancoAngeli, pp. 2092-2 109. 


\title{
Digital Survey of a Building Site of the Fifteenth Century: the Sagrestia Vecchia in San Lorenzo
}

\author{
Matteo Bigongiari
}

Abstract

The paper describes the digital architectural survey and documentation project of the Sagrestia Vecchia of the San Lorenzo complex in Florence, designed by Filippo Brunelleschi. First of all, the historical and cultural conditions that led to the urban design of a new complex for San Lorenzo are briefly described: the Sacristy was the first building built, following the new trend of styles and proportions that drew on ancient architecture. Subsequently the digital survey methodologies are described that were necessary to set up a documentation project that investigates and deepens the historical and construction events of the factory. The particular pandemic conditions prevented completing the photographic acquisitions of the surfaces until after summer 2020; this is the reason why the drawings and the detailed architectural surveys were carried out following the morpho-metric indications provided only by the data coming from the laser scanner.

This particular condition provided the opportunity to investigate the descriptive criticalities of point clouds, especially when dealing with architectures with complex architectural elements. Finally, the intentions and direction of future research are shown, which, starting from the findings acquired, will investigate the issues of the construction and stratification of the complex with the aim of disseminating information through digital interactive fruition systems.

Keywords

Sagrestia Vecchia, Brunelleschi, Renaissance, drawing, architectural survey.

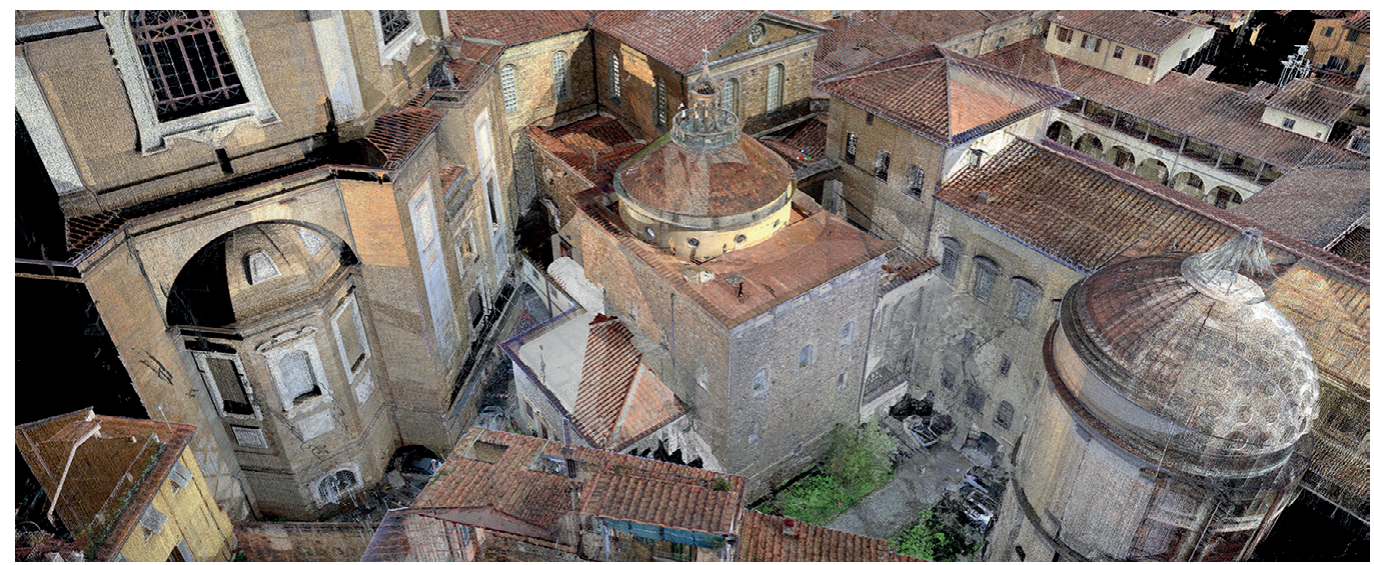




\section{Introduction}

In February 2020, a research project on the San Lorenzo complex began, aimed at returning, as a first sample case, the image and forms of one of the buildings that most representative of the new architecture of the Florentine Renaissance: Brunelleschi's Sagrestia Vecchia.

This article, introducing the building in the historical and cultural context in which it was built, illustrates the digital architectural survey methodologies adopted and the first results obtained from graphic renderings, proposing some preliminary considerations to be developed within the project to increase knowledge of the building, with particular attention to dissemination and enhancement of research products.

Producing research on well-known and studied buildings always hides the risk of not obtaining innovative results from a historical and architectural point of view, despite the indisputable graphic quality that is expected to be obtained from the drawings, which is mainly due to the compositional characteristics of the object. The approach to the study of architectures produced by important Renaissance artists has however already highlighted in other researches [I] how a holistic cognitive approach, strongly focused on the morphological analysis of architectures on the basis of a highly reliable survey, can highlight characteristics and information left out from previous research. In the same way, the strong scientific convictions, relating to architectures that have now become a symbol of a cultural movement of rebirth and rediscovery of Roman compositional and functional traditions, deserve to be studied and analyzed in relation to their cultural context of profound mutation of the formal and decorative characteristics of the public and sacral spaces. It is equally true that compared to other great architects of the mature Renaissance, people like Brunelleschi have not passed a fortunate period in recent decades from the point of view of the interest of scholars, especially due to the scarce documentation relating to the work of the Florentine architect, despite being one of the few to have had a personal biographer who also took care of completing the many works left unfinished on Filippo's death, such as the San Lorenzo complex.

\section{Brief notes on a project from the 15th century}

Analyzing the forms of architecture requires close attention to all the components that led to its construction, in particular to the surrounding conditions of the context, both historical-cultural and strictly morphological-urban. The creation of one of the architectural symbols of Renaissance modernity is due in principle to the abolition of the monastic orders which provoked the need to politically strengthen San Lorenzo, making it a well-functioning and virtuous religious cultural center for the city of Florence; these things happened before the Medici decided, after the mid-15th century, to privately assume the expansion of the complex as a family church [Battisti 1976].

The enlargement of the pre-existing medieval basilica included the enlargement of the rear part of the complex, with the construction of a large transept with sacristies and chapels [Pacciani 1995]; Brunelleschi's sacristy was built first between 1422 and I428, followed by the rest of the transept with numerous design changes, mainly due to the death of the prior, the need to finance the construction of the expensive factory and the increasingly present support of the Medici family. It is possible to see in an illustration of the Codex Rustici how the church must have looked during the construction of the transept, with the basilica still existing and functioning until 1465 and the completed Sacrestia Vecchia: it is evident how the project gradually, probably at the suggestion of Brunelleschi, led to the new construction of the entire religious building, completely modifying the first design intentions. At first, in fact, it was planned to add a transept on two levels that had to be connected with the ancient building, subsequently the ancient building was itself demolished and replaced by the current nave which hides an entire floor on the lower level, not perceived from the outside thanks to the inclusion of the large staircase that surrounds the monument. In the same 


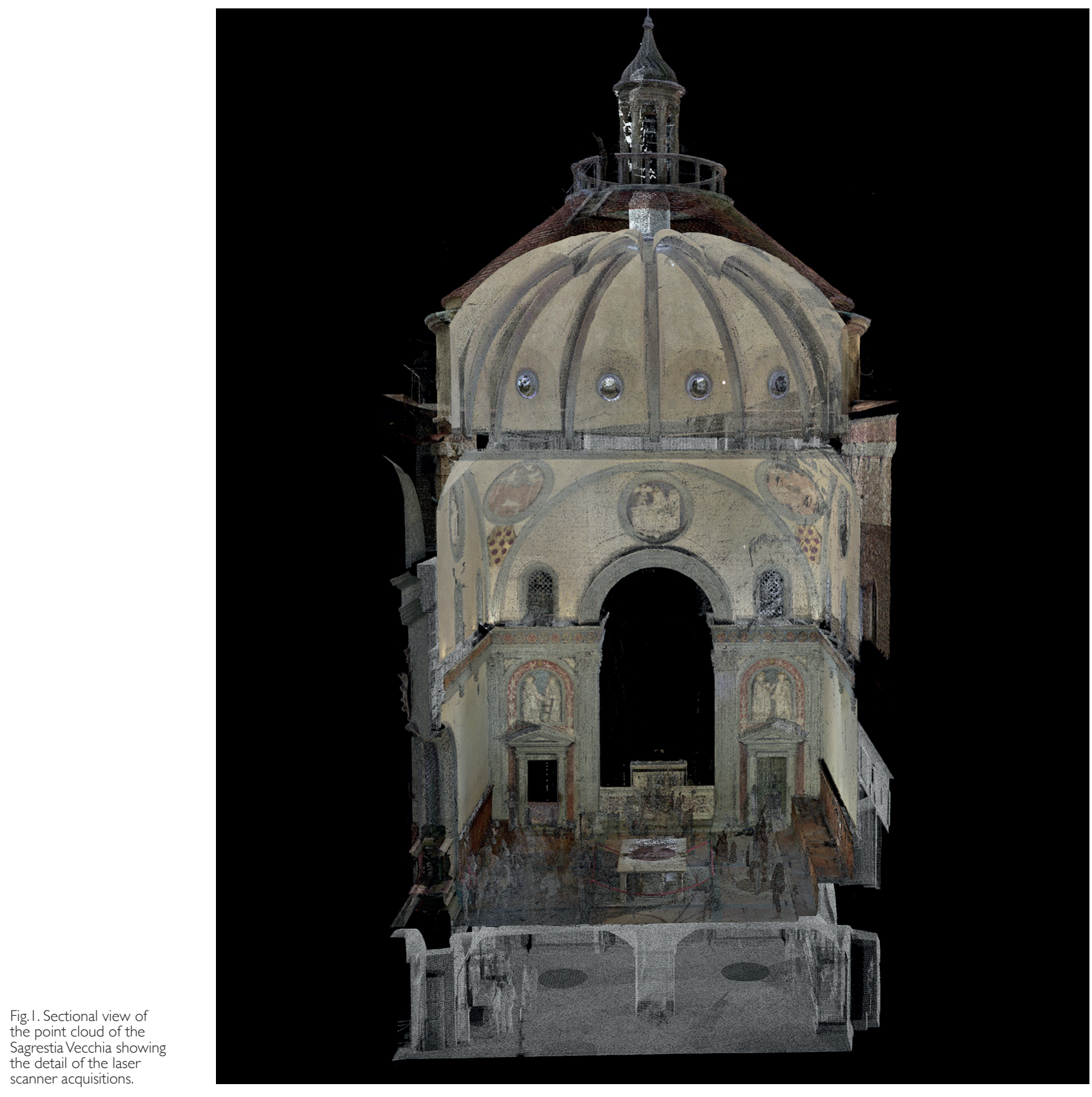

way, Brunelleschi's sacristy was also designed on two levels, a vaulted level at the height of the foundations of the future transept and the current floor level: the base on which the elevated floor of the sacristy is built can still be seen from the outside of the complex. This subdivision has led to the hypothesis that the exterior of the building was the same way as the interior designed in such a way as to recreate the idea of an architectural order: it had to appear plastered, resting on a base, and crowned by an entablature. The volume of the building today appears significantly different from the original construction, especially on the side of the scarsella, where the roofing structures were completely hidden by subsequent interventions that altered the perception of the building from the outside. It is not necessary to reiterate on this occasion the innovative conception of the internal space of the building where the architect has brilliantly managed to combine a quadrangular plan with the insertion of a circular dome [Bruschi 2006]. 


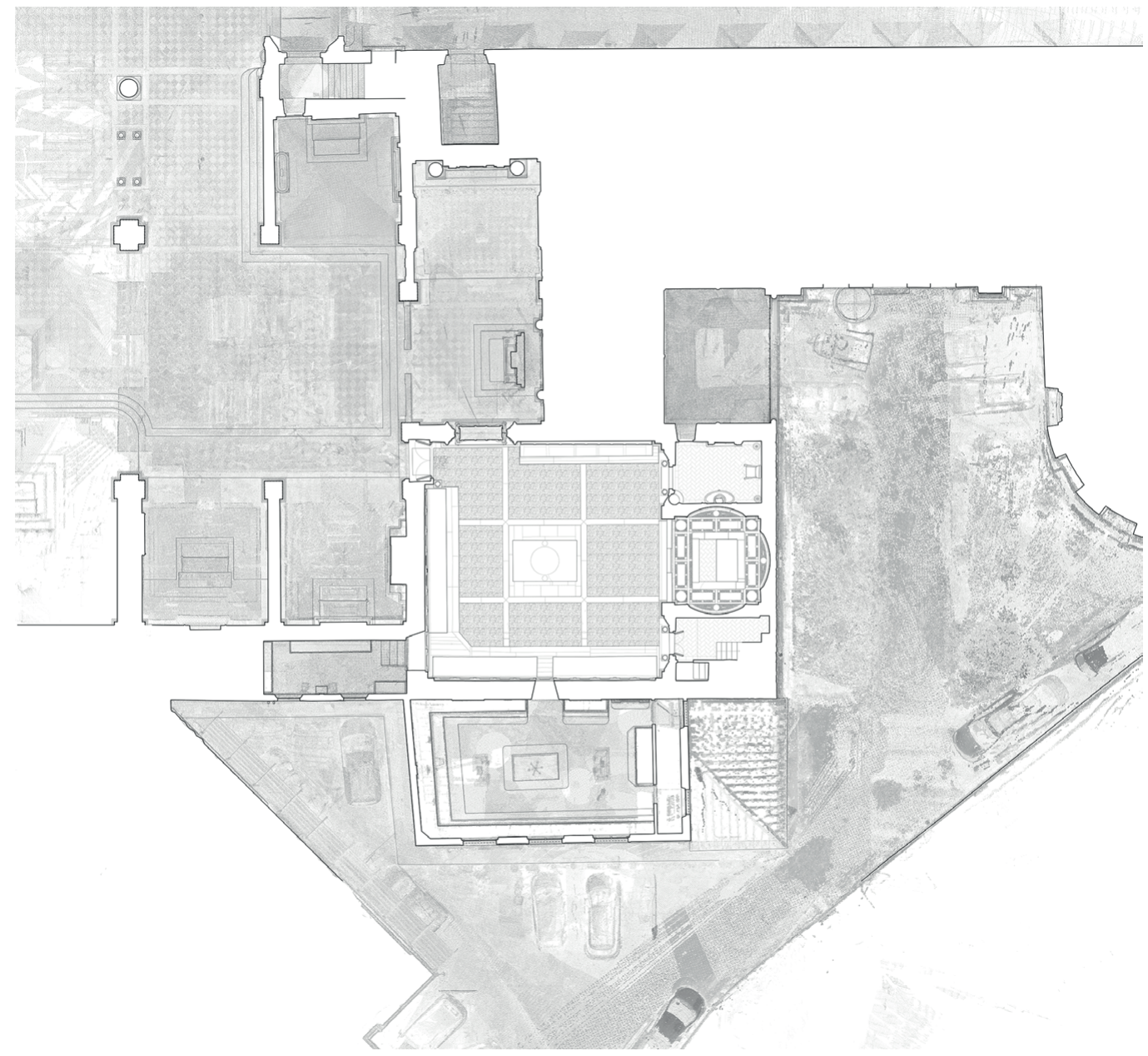

\section{The architectural survey of the Sacristy}

The study of Brunelleschi's architecture in the Sagrestia Vecchia could not begin without a first moment of direct knowledge of the building; for this reason, on February 2020, a few days before the closure of the town due to the health emergency, a campaign of digital surveys began to reconstruct the morphology of the fifteenth-century building. At first, the acquisitions of three-dimensional scans with laser scanners of the sacristy rooms were planned: unfortunately, due to the unexpected closure of the premises on March 2020, it was not possible to integrate the photographic data until September of the same year, imposing to design the digital survey at first only with scans as the only available tool [2]; the photographic documentation was not entirely absent: the shots necessary to describe the individual architectural elements had been correctly acquired, and it must also be considered that from each single scan it was possible to extract a high-resolution panoramic photograph; however, it was not possible to return the detail of the individual architectural elements starting from an orthoimage on an adequate scale, but simply from the laser scanner point clouds. The three-dimensional photogrammetric models were created at a later time by integrating the results of the wire drawing back.

The laser scanner survey of the sacristy was designed in such a way as to obtain an adequate data to allow the description of all the elements that characterize the internal space of the building, considering that the main characteristic of Brunelleschi's project consists in the creation of a simple space where the plastered walls, which make up most of the surfaces of the first register, had to enhance the contrast with the classical order, formed by Corinthian pilasters that mark the rhythm of the architecture. 
Fig. 3. Vertical section of the Sacristy showing access to the scarsell relationship with the surrounding structures.

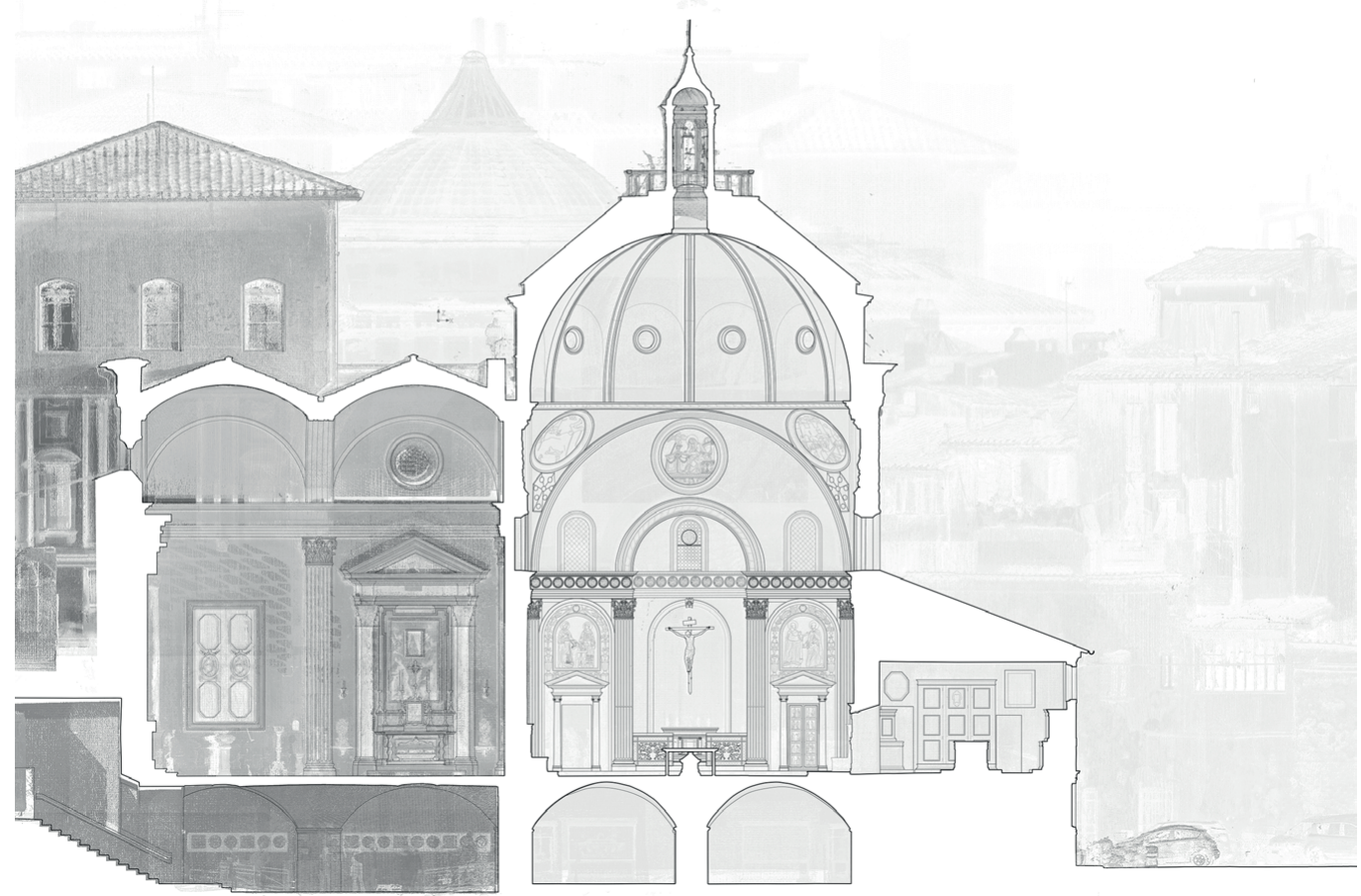

The scans were therefore designed in such a way as to ensure a high coverage of points for those complex surfaces, such as the rudent pilasters, the Corinthian capitals, the terracotta cherubs of the frieze, the decorative elements of the entablatures, the roundels and the wall that frames the scarsella, to name a few; obviously, as can be easily understood, the need to define the point cloud of these elements in detail has caused a general increase in the size of the morphological database of the sacristy, and also required the correct data acquisition design: in fact, a tool was used which guarantees high reliability in the measurements, and the scans have been made in such a way as to minimize the problems deriving from the "digital noise" that is usually created every time the laser beam encounters an edge [3]. The exterior of the sacristy and the not richly decorated interior rooms such as the main hall and the chapel required less dense data and were acquired more quickly.

The management of the scans data has provided for an adequate filter phase to further limit errors in the punishments acquired; the registration phase of the scans, thanks to the modern technology of the instrument used [4], begins while the scan acquisition proceeds: once the data has been acquired, it is transferred directly via wi-fi to a computer, and pre-aligned [5] with the previous scans, which allows you to finish the survey in the field with all scans correctly oriented in a single reference system. The post-production registration phase therefore required the optimization of the pre-alignment and a subsequent phase of certification of the data through the analysis of the section profiles of the scans which made it possible to establish the degree of reliability of the registration [6]. From the general model obtained, the high-definition ortho-images useful for polishing the main sections on autocad were extracted, tracing the point cloud to a CAD drawing that was able to divide both the objects from a semantic point of view and from the point of view of graphic weight lines in the representation. 
Fig. 4. Detail from a cloud of points of a Corinthian pilaster of the Sacristy, despite the high detail, due to overhangs and shaded areas it is not possible to easily understand all the contours that describe the architecture.

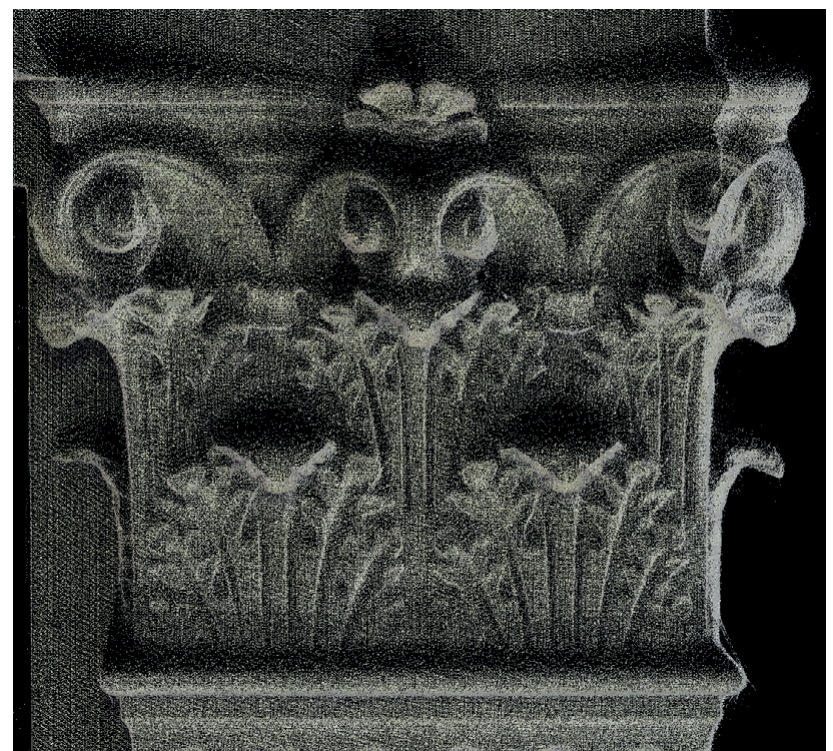

\section{The problems of digital survey}

The particular condition in which the surveys of the Old Sacristy were graphically created allowed us to deepen some reflections on the problems related to the interpretation of the point clouds: as was anticipated, the health emergency forced students and teachers to carry out the activity mainly from home, using only the data coming from the laser scanner scans produced in a quick day of measurements. The main challenge was therefore to verify whether the morphological information obtained from the 3D scans were sufficient to be able to understand the forms of architecture and to draw technical drawings, therefore architectural surveys also at a detailed scale. The compositional characteristics of the building, namely the presence of architectural elements particularly rich in decorations, with the presence of carved details and numerous bas-reliefs, made the graphic rendering even more complicated. The problematic presence of richly decorated elements highlights an intrinsic problem of laser scanner tools commonly used for architectural surveys, which consists in not being able to correctly define the edges of the surfaces, which are instead, as far as the drawing is concerned, the necessary points to define the outlines of objects [Rinaudo 2017]. This difficulty is solved in the architectural survey with an acquisition of points so massive as to minimize the error in the representation with respect to the drawing restitution scale, but at the expense of an excessive storage of morphological information, such as not to allow the rapid management of the databases, and mostly often unnecessary: as regards the Sacristy, for example, if a very dense datum of points is useful for the correct interpretation of the architectural order, at the same time most of the surfaces are plastered and not they need the same acquisition density. A further complexity in the correct definition and understanding of the survey derives from the evident lack of data due to the overhang of some decorative elements: this problem cannot be solved during the acquisition phase directly with a terrestrial laser scanner, because the lack of data cannot be solved; to resolve the issue, on the other hand, attention must be paid to the survey phase in the field and to record the forms of architecture on a manual support (through clarifying drawings or photographs). For these issues, the figure of the architect remains irreplaceable who not only manages to understand and integrate the absent digital data, but, knowing the forms of classical architecture, is able to distinguish, even in the presence of digital noise, the morphological characteristics of the decorative and architectural elements of the classical order and translate them into understandable and morphologically correct drawings [Migliari 1991]. 
Fig. 5. Photogrammetric model of the Sacristy useful for the integration of the given color.

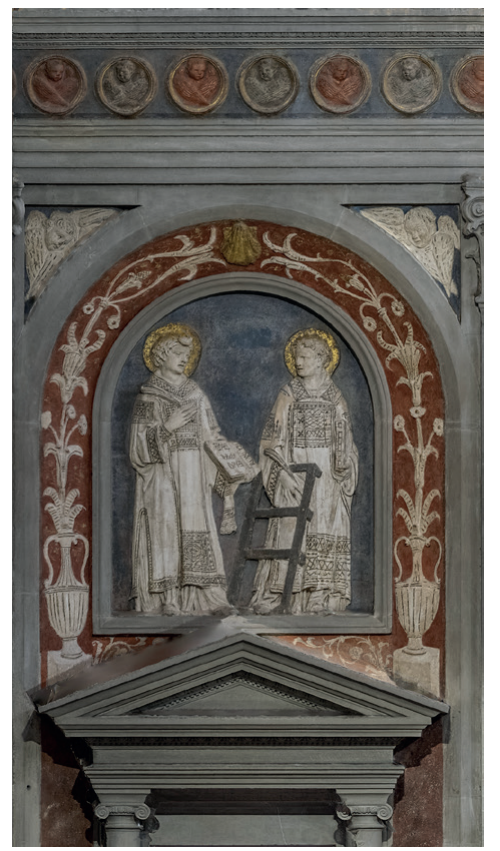

\section{Conclusions and developments of the project}

As can be seen from the images that illustrate the results of the graphic processing, it was possible to achieve a high degree of definition by drawing only on the basis of the laser scanner point cloud. The construction of the textures started only after the realization of the drawings and will lead to the integration of all the surfaces with the color data; the presence of numerous plastered walls required to evaluate the integration of information from photographic cameras and laser scanners in the photogrammetric reconstruction, leading to interesting results.

The architectural surveys carried out through this documentation project allow us to describe, with adequate in-depth analysis, all the wall faces of the Brunelleschi Sacristy: these data will be necessary, together with the products of an adequate historical archival re-
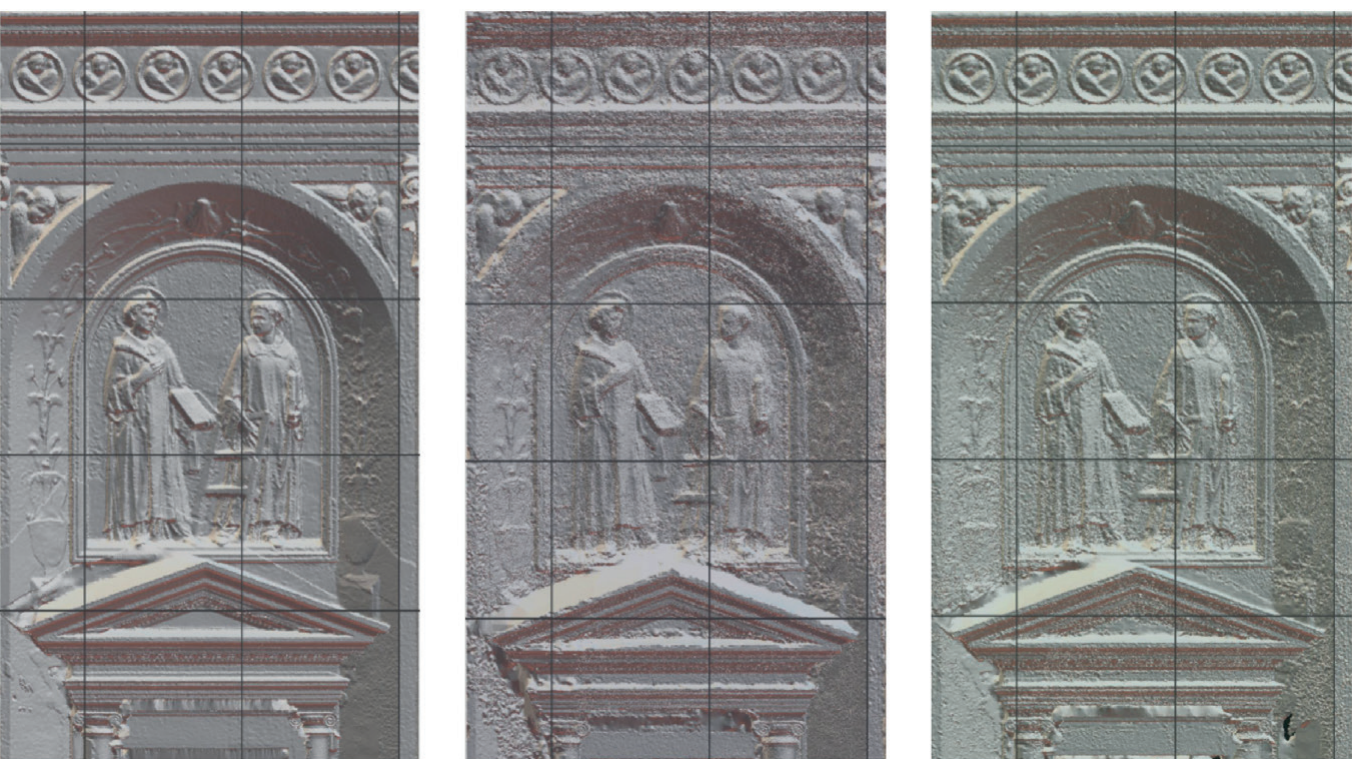

Fig. 6. Comparison between

photogrammetric

the left was created by

creating a mesh starting

from the laser scanner

data only; the second

from the photographic

Sony alfa7); the third by

integrating both scanner and photographic data

It is evident that the first

model guarantees a more

adequate morphology

architecture. 
Fig. 7. Texture coming from the coloring of the models described in the previous image, the detail on Donatello's decorations made it possible to verify the correctness of the wire drawing

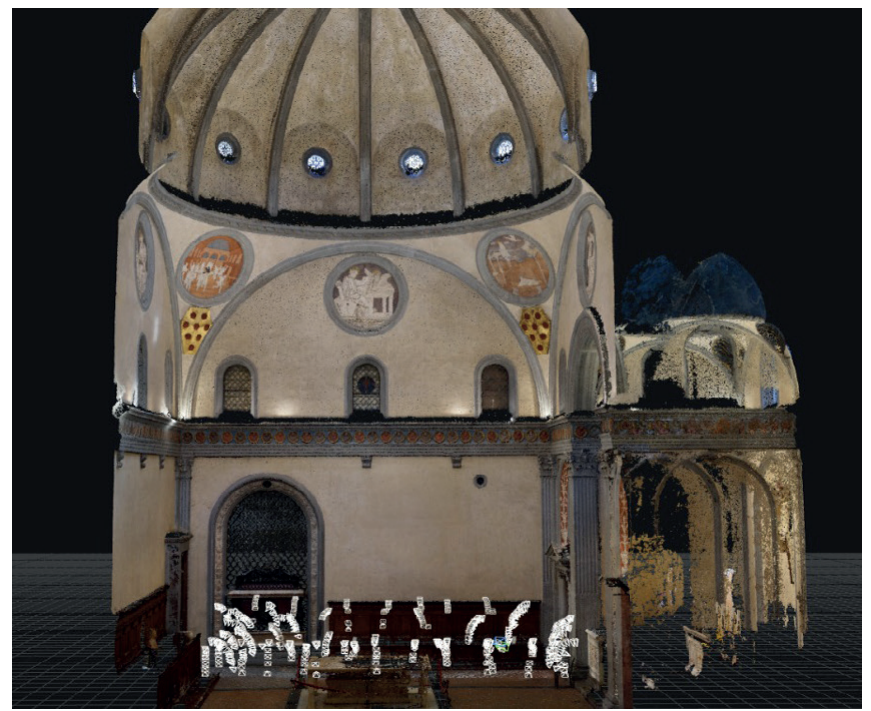

search, to deepen the design, construction and stratification processes that followed one another in the San Lorenzo factory.

The surveys provided the opportunity to compare the drawings made by Sanpaolesi in the mid-1900s and the more in-depth ones published by Gurrieri, to verify the morphological data and information regarding the structures of the sacristy, however integrating a large part of the interior decoration and restoring a more complete picture of the architecture of the sacristy. The careful analysis of Brunelleschi's construction will show how the theme of the design of square chapels with domes on pendentives was not completely resolved in the design example of the Sagrestia Vecchia: this is not the occasion to deepen the subject but evident inconsistencies on the modulation of the order are still partly visible and partly hidden by the construction of the subsequent connection with the transept; to clarify this aspect it will be necessary to make a careful comparison with the Pazzi Chapel, built after the Sagrestia Vecchia, for which a new digital documentation project has just begun. The drawings obtained will be fundamental for the reconstruction of the construction phases of the factory, for which a careful analysis of the masonry stratigraphy will be necessary at least as regards the external fronts in pietra forte; the presence of a detailed three-dimensional survey could be the starting point for the construction of digital models that illustrate the construction of the building and its subsequent evolution, enhancing and showing the history of the monument to the public through the use of virtual reality platforms, which must have been thought to have an external image and a completely different lighting from what we can see today.

\section{Notes}

[I] For an innovative contribution on Leonardo da Vinci's military architecture see: Bertocci, Bigongiari 202I.

[2] The architectural survey of the Sacristy was the subject of a digital survey seminar held within the educational program of the School of Specialization in Architectural and Landscape Heritage of the Department of Architecture.

[3] Specifically, a Z + F 5016 instrument was used, which has nominal errors on measurements less than Imm; each scan was carried out in such a way as to guarantee a high coverage of points on each surface, at least 4 points every $\mathrm{cm}$, and at a high quality, which required to measure each point at least 4 times, thus limiting any problems of digital noise.

[4] the instrument has internal sensors, inertial platform and GPS, which allow the data management software directly in the field to recognize the movements of the laser scanner stations.

[5] the management of the final registration was carried out with the Leica Cyclone 9.4 software.

[6] the problem of the certification of the alignment error in a laser scanner survey carried out without any other support survey method (topographic or gps) is a research topic that has made it possible to significantly speed up the architectural survey [Bigongiari 2020] 
Fig. 8. Orthoimage of the exterior of the dome of the Sacristy, where you can see the unique structure with an Arabian-style dome positioned on the top (restoration by Sanpaolesi).

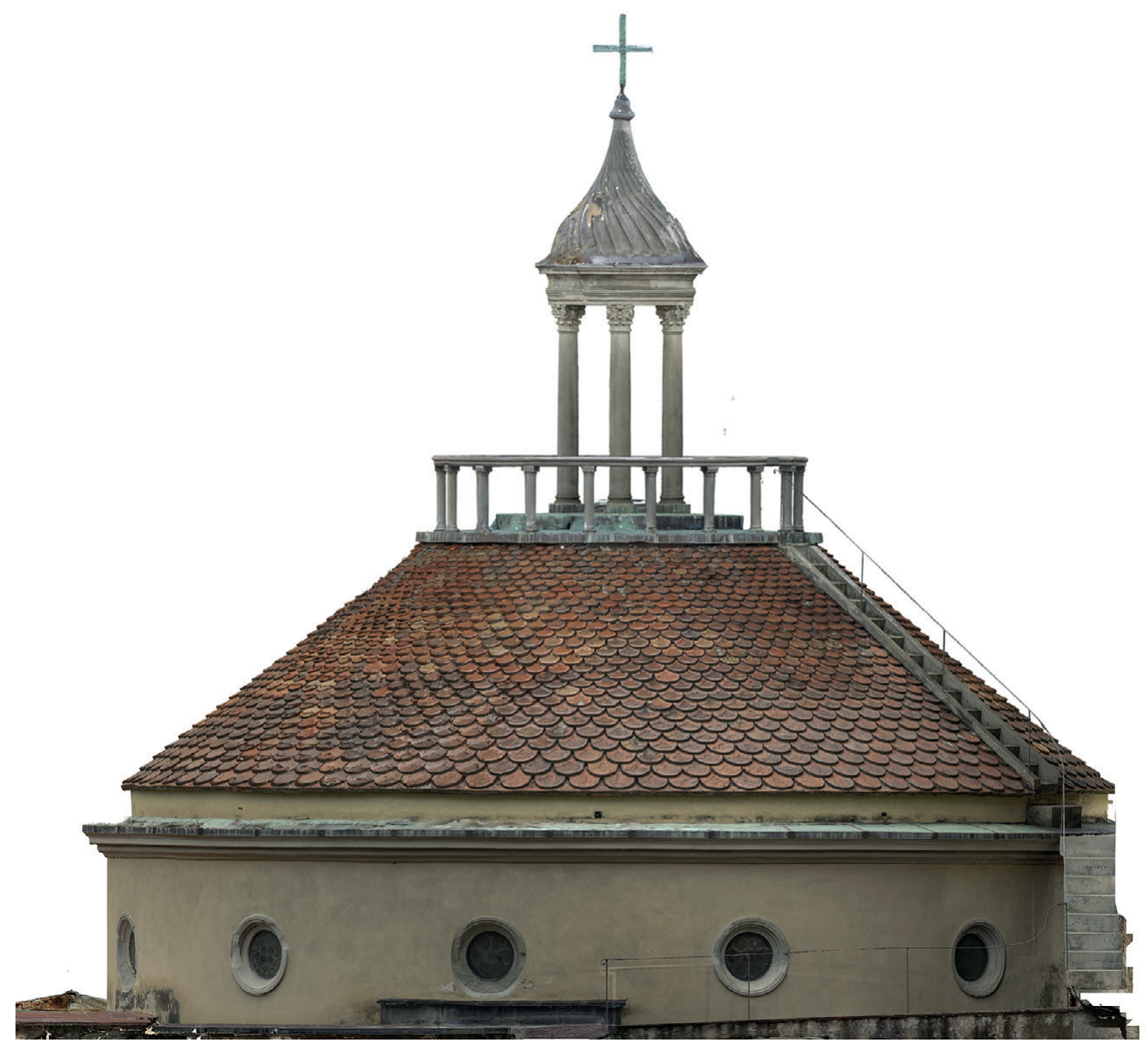

\section{References}

Battisti E. (1976). Filippo Brunelleschi. Milano: Electa.

Bertocci S., Bigongiari M. (2020). Le fortificazioni di Piombino di Leonardo da Vinci: la riscoperta delle tracce dell'impianto rinascimentale attraverso il rilievo digitale e il disegno. In Arena A. et al. (a cura di). Connettere. Un disegno per annodare e tessere. Atti del $42^{\circ}$ Convegno Internazionale dei Docenti delle Discipline della Rappresentazione/Connecting. Drawing for weaving relationships. Proceedings of the 42th International Conference of Representation Disciplines Teachers. Milano: FrancoAngeli, pp. $87-$ I 02.

Bigongiari M. (2020). La cattedrale di Sasamòn. Rilievo digitale e strutturale per la conservazione del Patrimonio. Firenze: Didapress. Bruschi A. (2006). Filippo Brunelleschi. Milano: Electa.

Migliari R. ( I99|). II disegno degli ordini e il rilievo dell'architettura classica: 5 pezzi facili. In Disegnare. Idee Immagini, n. 2, pp. 49-66.

Pacciani R. (1995). Testimonianze per l'edificazione della basilica di San Lorenzo a Firenze, | 42 I- | 442. In Prospettiva, n. 75-76, pp. 85-99.

Rinaudo F. (2017). Analisi della qualità del rilievo laser scanner architettonico e criteri di verifica, In G. Pancani. La città dei Guidi: Poppi Il costruito del centro storico, rilievi e indagini diagnostiche. Firenze: Firenze.

Sanpaolesi P. (1947). Brunellesco e Donatello nella Sacrestia Vecchia di San Lorenzo. Pisa: Nistri-Lischi Editori.

Author

Matteo Bigongiari, Università di Firenze, matteo.bigongiari@unifi.it

To cite this chapter. Bigongiari Matteo (2021). II rilievo digitale di una fabbrica del Quattrocento: la Sagrestia Vecchia di San Lorenzo/Digital Survey of a Building Site of the Fifteenth Century: the Sagrestia Vecchia in San Lorenzo. In Arena A., Arena M., Mediati D., Raffa P. (a cura di). Connettere. Un disegno per annodare e tessere. Linguaggi Distanze Tecnologie. Atti del $42^{\circ}$ Convegno Internazionale dei Docenti delle Discipline della Rappresentazione/ Connecting. Drawing for weaving relationship. Languages Distances Technologies. Proceedings of the 42th International Conference of Representation Disciplines Teachers. Milano: FrancoAngeli, pp. 2092-2109. 